\title{
Perancangan Aplikasi Virtual Reality 360 Berbasis Web di Universitas Advent Indonesia
}

\author{
Sozanolo Gea*1, Raymond Maulany² \\ 1,2Fakultas Teknologi Informasi, Universitas Advent Indonesia \\ e-mail: *11382005@unai.edu, 2raymond@unai.edu
}

\begin{abstract}
Abstrak
Sekarang ini, aplikasi web telah banyak yang bersifat dinamis dan interaktif untuk diterapkan dalam Sistem Informasi, Telekomunikasi, Perdagangan, Perbankan, Pendidikan dan berbagai jenis lainya. Seiring dengan perkembangan tersebut. Penulis ingin membuat Virtual Reality UNAI yang bertujuan untuk membantu pengunjung website melihat kampus UNAI lebih dekat. Tujuan Penelitian ini adalah: (1)Membuat Virtual Reality 360o untuk Universitas Advent Indonesia. (2)Menyajikan gambar 360o Melalui website Universitas Advent Indonesia. (3)Membuat pengunjung website Universitas Advent Indonesia dapat lebih mudah mengenali lokasi dan lingkungan sekitar UNAI yang disajikan dalam bentuk Virtual. Adapun kesimpulan dari Penelitian ini adalah: (1) Aplikasi Virtual Reality 360o dapat diimplementasikan kedalam website Universitas Advent Indonesia. (2) Aplikasi Virtual Reality 3600 ini menarik, interaktif dan mudah digunakan sehingga memudahkan user untuk memperoleh informasi tentang lingkungan UNAI. Metode yang digunakan dalam perancangan aplikasi virtual Reality ini menggunakan model pengembangan waterfall. Metode pengembangan sistem waterfall. Model SDLC air terjun (waterfall) sering juga disebut model sekuensial linier (sequential linier). Aplikasi yang dirancang dapat menampilkan gambar 360o dari beberapa sudut kampus dalam bentuk web interaktif.
\end{abstract}

Kata-kata kunci: Virtual Reality, 360 View, Waterfall, Web Based.

\section{Design of Web Based 360 Virtual Reality Application at Universitas Advent Indonesia}

\begin{abstract}
Today, many web applications are dynamic and interactive to be applied in Information Systems, Telecommunications, Trade, Banking, Education and various other types. Along with these developments. The author wants to create UNAI Virtual Reality which aims to help website visitors see the UNAI campus more closely. The objectives of this study are: (1) Creating a Virtual Reality 3600 for Adventist University of Indonesia. (2) Presenting 3600 images through the website of the Adventist University of Indonesia. (3) Making visitors to the Adventist University website Indonesia more easily recognize the location and environment around UNAI which is presented in a Virtual form. The conclusions from this study are: (1) The Virtual Reality 3600 application can be implemented on the website of the Adventist University of Indonesia. (2) The Virtual Reality 3600 application is interesting, interactive and easy to use, making it easier for users to obtain information about the UNAI environment. The method used in designing this virtual reality application uses the waterfall development model. Method of developing a waterfall system. The SDLC model of waterfall is often also called a linear sequential model. The application designed can display 360 images from several corners of the campus in interactive web forms.
\end{abstract}

Keywords: Virtual Reality, 360 View, Waterfall, Web Based. 


\section{Pendahuluan}

Pada saat ini, dunia semakin maju pesat dalam berbagai bidang komunikasi dan sarana. Maka perkembangan aplikasi web yang semakin pesat sejak munculnya teknologi internet dalam kehidupan nyata, sangat membantu dalam memudahkan penyampaian dan penerimaan informasi serta kecepatan dalam pengiriman sudah semakin canggih seiring berkembangnya teknologi pada zaman ini. Sekarang ini, aplikasi web telah banyak yang bersifat dinamis dan interaktif untuk diterapakan dalam Sistem Informasi, Telekomunikasi, Perdagangan, Perbankan, Pendidikan dan berbagai jenis lainya. Salah satu aplikasinya yaitu Word Wide Web (www) yang secara umum artinya adalah adalah suatu media pada teknologi internet yang bekerja untuk menampilkan informasi dalam bentuk text, gambar, suara, bahkan video pada sebuah aplikasi yang bernama browser.

Tetapi pada saat sekarang ini telah munculnya aplikasi Virtual Reality yang membuat User seakan berada dalam dunia nyata dan banyak yang tertarik untuk mengaplikasikannya dalam bentuk promosi berbagai institusi. Secara umum Istilah Virtual Reality adalah teknologi yang memungkinan pengguna bisa berinteraksi terhadap objek nyata yang disimulasikan menggunakan komputer.

Universitas Advent Indonesia dalam promosi kampus telah menggunakan beberapa cara di antaranya website, brosur, serta kunjungan ke Sekolah - sekolah menengah atas, namun dari media promosi yang telah ada, masyarakat hanya mengenal Universitas Advent Indonesia dalam bentuk gambar 2 dimensi. Untuk dapat memperkenalkan lingkungan dan keadaan kampus berserta dengan fasilitas yang ada di Universitas Advent Indonesia, penulis tertarik membuat Virtual Reality (VR) 360o yang mampu membawa pengguna seolah - olah berada dalam lingkungan Universitas Advent Indonesia.

Dengan adanya Website, Universitas Advent Indonesia mudah diketahui oleh banyak orang sehinggal secara tidak langsung, Universitas Advent Indonesia mempromosikan dirinya kepada semua orang yang mengunjungi websitenya, sebaliknya pengunjung website juga dapat mengetahui segala sesuatu yang terdapat dalam Universitas Advent Indonesia tentunya dengan semua kelebihan yang ada didalamnya dengan cepat tanpa harus menghabiskan waktu untuk berkunjung langsung Universitas Advent Indonesia. Maka aplikasi Virtual Reality ini adalah satu sarana untuk semua mahasiswa yang tidak mengetahui dimana dia akan berkuliah, dan dengan adanya Virtual Reality ini dia bisa menentukan pilihannya sendiri dengan ketertarikan yang ditawarkan berbagai kampus khususnya Universitas Advent Indonesia. Virtual Reality adalah pemunculan gambar-gambar tiga dimensi yang di bangkitkan komputer, yang terlihat nyata dengan bantuan sejumlah peralatan tertentu. Ciri terpentingnya adalah dengan menggunakan perangkat yang dirancang untuk tujuan tertentu, teknologi ini mampu menjadikan orang yang merasakan dunia maya tersebut terkecoh dan yakin bahwa yang dialaminya adalah nyata.

\section{Landasan Teori}

\section{Internet}

Menurut Ahmadi dan Hermawan [1], Internet adalah komunikasi jaringan global yang menghubungkan seluruh komputer di dunia meskipun berbeda sistem operasi dan mesin. Menurut Hidayat [2] "Internet adalah jaringan global yang menghubungkan komputer - komputer di seluruh dunia." Menurut Talib H. [3] saat ini layanan yang tersedia di internet sudah sangat beragam, mulai dari WWW (World Wide Web), FTP (File Transfer Protocol), Email, Chat, IM (Instant Messaging), dan sebagainya. Bahkan, layananlayanan tersebut menjadi semakin berkembang lagi sehingga layanan di luar Internet itu sendiri, seperti pengiriman SMS ke handphone dan sebagainya.

\section{Web}

World Wide Web (www) atau web adalah sebuah sistem penyebaran informasi melalui internet. Informasi yang dikirimkan dapat berupa teks, suara (audio), animasi, gambar dan bahkan dalam format video yang dapat diakses melalui sebuah software yang disebut browser, seperti Internet Explorer, Mozilla Firefox, Opera, dan lain-lain. Umumnya halaman web ditulis dengan HTML dan ditransmisikan dengan 
Perancangan Aplikasi Virtual Reality 360 Berbasis Web di Universitas Advent Indonesia

protokol HTTP. Sebuah software, yang disebut dengan Web Browser, dibutuhkan untuk melihat halaman Web. Dalam perkembangannya, Web berkembang semakin dinamis dengan memasukkan berbagai teknologi Web lain seperti Javascript/Jscript, CSS, XML, DOM, PHP, CGI, Plug-in, ActiveX Control, dll. Dengan teknologi yang disebut terakhir, dapat dikatakan hampir seluruh aplikasi dapat diintegrasikan (embedded) dalam halaman Web.

\section{Aplikasi Web}

Menurut Shalahuddin dan Rossa [4], aplikasi web merupakan halaman dinamis yang mengizinkan interaksi dengan user (user melakukan sesuatu). Interaksi user dengan aplikasi web misalnya user mengeklik sebuah tombol dan warna latar belakang web berubah.

Menurut Kadir [5], aplikasi web dibangun dengan menggunakan bahasa yang disebut HTML (HyperText Markup Language). Aplikasi web dibagi menjadi dua yaitu: web statis, dan web dinamis. Web statis dibentuk dengan menggunakan HTML, dan kelemahan aplikasi ini terletak pada keharusan untuk memelihara program secara terus-menerus untuk mengikuti setiap perubahan yang terjadi. Sedangkat aplikasi web dinamis dapat menutupi kelemahan tersebut dengan memperluas kemampuan HTML dengan perangkat lunak tambahan.

Menurut Raghib [6], Secara Umum World Wide Web atau WWW atau dikenal dengan WEB adalah salah satu layanan yang didapat oleh pemakai komputer yang terhubung ke internet. Web ini menyediakan informasi bagi pemakai komputer yang terhubung ke internet dari sekedar informasi "sampah" atau informasi yang tidak berguna sama sekali sampai informasi yang serius; dari informasi yang gratisan sampai informasi yang komersial. Website atau situs dapat diartikan sebagai kumpulan halaman-halaman yang digunakan untuk menampilkan informasi teks, gambar diam atau gerak, animasi, suara, dan atau gabungan dari semuanya itu baik yang bersifat statis maupun dinamis yang membentuk satu rangkaian bangunan yang saling terkait dimana masing-masing dihubungkan dengan jaringan-jaringan halaman (hyperlink).

Menurut Shalahuddin dan Rossa [4], mengatakan bahwa aplikasi berbasis web dapat juga dijalankan sebagai script oleh processor semacam ASP atau PHP. Script dan program tersebut akan memberikan informasi dalam format HTML ke web server untuk diteruskan ke browser dan juga memproses informasi dari web server, misalnya menyimpan data ke basis data. Aplikasi web biasanya dibuat dengan menggunakan JavaScript, aplikasi flash, atau applet pada Java.

\section{Virtual Reality}

Definisi Virtual Reality menurut Michael, Novak, Begus [7] mendefinisikan Virtual Reality terdiri dari sebuah simulasi komputer interaktif, yang indra negara pengguna dan opreation dan menggantikan atau menambah informasi umpan balik indera ke satu atau lebih indera dengan cara yang pengguna dapatkan rasa yang tenggelam dalam simulasi virtual reality. Virtual Reality adalah Observasi dari lingkungan virtual melalui sistem yang menampilkan objek dan memungkinkan interakasi, sehingga menciptakan kehadiran virtual.

Menurut Fuchs, Moreau, Guitton[8], Virtual Reality adalah domain ilmiah dan teknis yang menggunakan ilmu komputer dan antarmuka perilaku untuk mensimulasikan di dunia maya perilaku entitas 3d, yang berinteraksi secara real time dengan satu sama lain dan dengan satu atau lebih pengguna. Tujuan Virtual Reality adalah untuk memungkinkan sebuah aktivitas kognitif untuk orang (orang) di dunia buatan dibuat secara digital, yang dapat imajiner, simbolik atau simulasi aspek-aspek tertentu dari dunia nyata.

Menurut Suyanto [9], mendefenisini virtual reality adalah lingkungan tiruan yang diceptakan dengan perangkat keras dan perangkat lunak komputer dan disajikan kepada pemakai sehigga pemakai tersebut merasa seperti dalam dunia nyata. 


\section{Analisa dan Perancangan Aplikasi}

\section{Metode Perancangan}

Dalam perancangan aplikasi Virtual Reality ini penulis menggunakan struktur navigasi, untuk melihat proses aplikasi yang mencakup proses input dan proses output. Pada tahap ini digunakan notasi-notasi untuk menggambarkan arus data dimana akan sangat membantu dalam proses komunikasi dengan pemakai sehingga dapat dimengerti. Struktur Navigasi

Struktur navigasi menunjukkan, Halaman Virtual Reality menjadi yang pertama pada aplikasi Virtual Reality yang akan dibangun. Karena melalui halaman ini, user dapat mengakses aplikasi Virtual Reality.

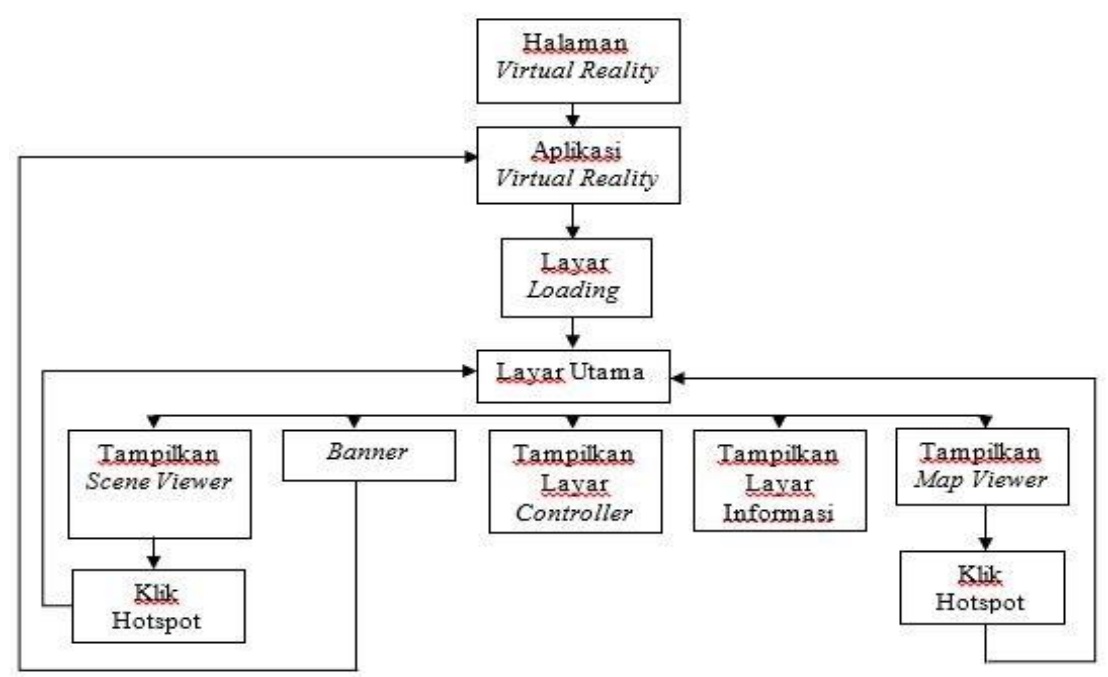

Gambar 1 Navigasi Aplikasi

User akan berada pada navigasi halaman Virtual Reality untuk mengakses aplikasi Virtual Reality. Apabila diklik oleh user pada aplikasi Virtual Reality akan muncul layar loading. Setelah layar loading, akan ditampilkan layar utama aplikasi Virtual Reality, Layar loading atau bisa disebut juga splash screen tampil pertama kali pada aplikasi ini. Kemudian dilanjutkan pada Layar Utama. Layar utama ini memiliki objekobjek sebagai berikut :

1. Scene Viewer

Objek tersebut adalah sebuah layar untuk menampilkan foto panorama untuk dapat ditampilkan secara immersion dan juga ditambah titik hotspot yang dapat dipilih untuk mendapatkan pengalaman Virtual Reality yang interaktif.

2. Banner

Banner yang penulis gunakan dalam aplikasi Virtual Reality ini berupa logo UNAI yang digunakan sebagai hyperlink untuk menuju ke halaman utama aplikasi Virtual Reality.

3. Layar Informasi

Objek ini berupa textfield yang digunakan untuk menampilkan informasi dari lokasi yang ditampilkan di Scene Viewer.

4. Map

Objek yang digunakan untuk me lihat lokasi dalam peta, yang juga memiliki titik- titik hotspot yang dapat dipilih untuk pindah ke lokasi tersebut dalam Scene Viewer. Objek ini dapat ditampilkan dan disembunyikan. 


\section{Tombol Controller}

Tombol-tombol pengontrol gambar panorama 360 o pada scene viewer sehinggal gambar bergerak sesuai dengan keinginan User.

\section{Hasil Perancangan Aplikasi}

\section{Tampilan Layar Utama}

Pada layar utama ini, akan muncul logo kampus Universitas Advent Indonesia, tombol Map dan tombol controller. Disini terdapat juga tombol yang berupa "Hotspot" yang dapat mebawa User ke lokasi lain yang dituju apabila di klik, dan terdapat tombol Informasi dari tempat yang menjadi objek Virtual Reality.

Pada layar utama ini, tombol - tombol serta layar mempunya fungsi:

1. Layar "Info" menampilkan Informasi Scene.

2. "Map" menampilkan Peta UNAI.

3. Tombol "controller" untukp mengontrol gambar Virtual Reality.

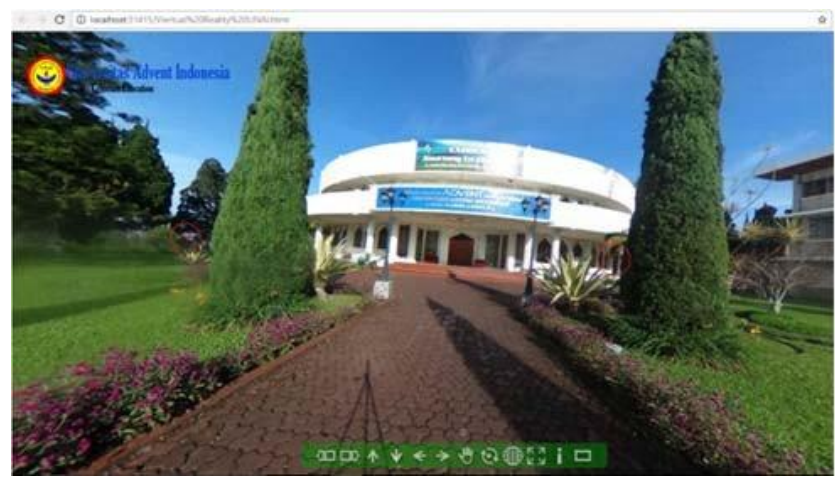

Gambar 2 Tampilan Layar Utama

\section{Tampilan Layar Loading}

Pada saat Aplikasi Virual Reality ini dijalankan, akan tampil layar loading dan juga ketika User mengklik hotspot yang menuju lokasi lain maka gambar loading ini akan muncul seperti yang ada pada gambar dibawah ini.

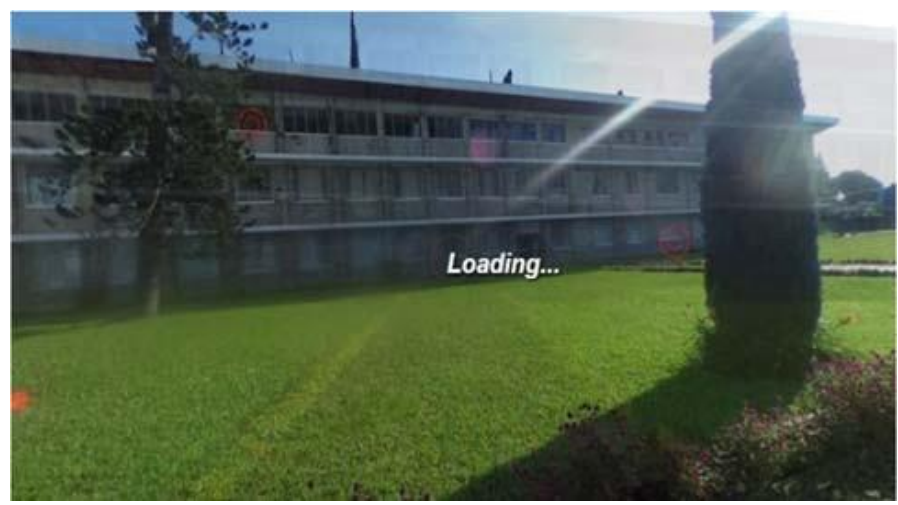

Gambar 3 Tampilan Layar Loading

\section{Tampilan Layar Scene Viewer}

Pada layar ini, menampilkan scene Virtual Reality yang telah dipilih. Disini terdapat titik hotspot yang dapat di klik untuk menuju ke lokasi yang telah ditentukan oleh hostpot tersebut. 


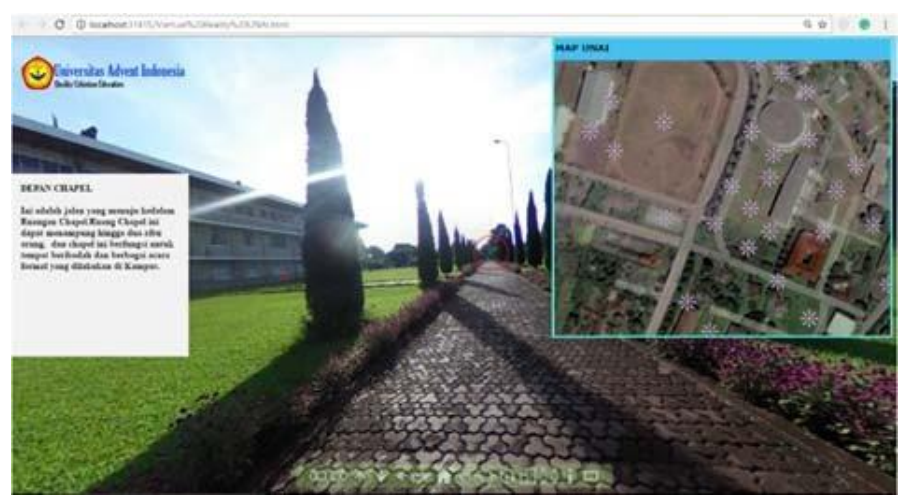

Gambar 4 Tampilan Layar Scene Viewer

\section{Tampilan Layar Map Viewer}

Pada layar ini, menu Map Viewer berfungsi untuk menampilkan peta lokasi UNAI keseluruhan. Pada peta ini terdapat titik - titik hotspot yang dapat di klik untuk menuju ke lokasi yang ditentukan dengan hotspot tersebut. Pada layar ini juga terdapat tombol Map yang dapat digunakan untuk menampilkan peta serta menyembunyikan peta.

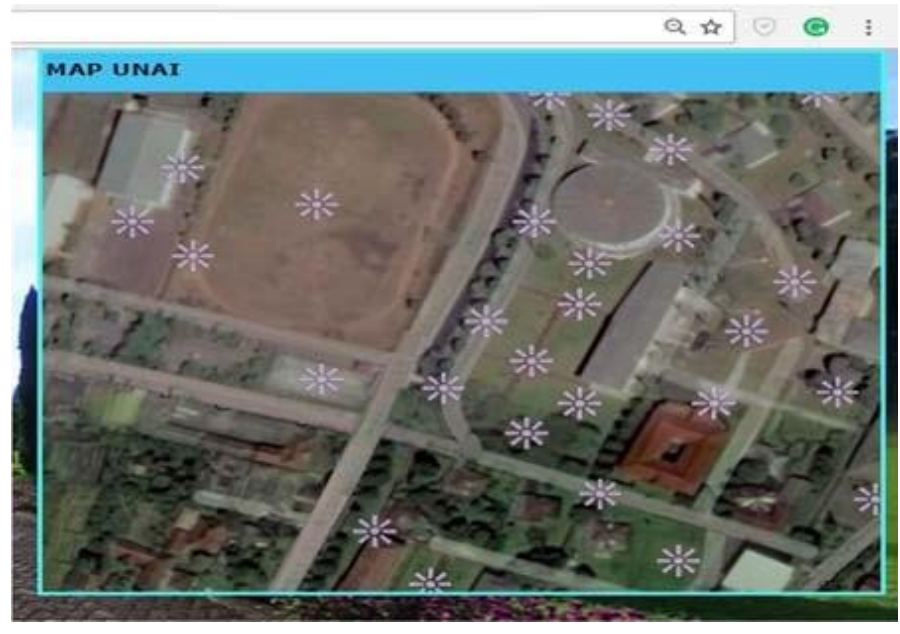

Gambar 5 Tampilan Layar Map Viewer

\section{Tampilan Lapangan Parkir}

Ini adalah Tempat Parkiran Para Staf dan Dosen UNAI, lokasi ini terletak dekat dengan old building, depan chapel dan dekat dengan gerbang UNAI seperti yang terlihat pada gambar dibawah ini. 


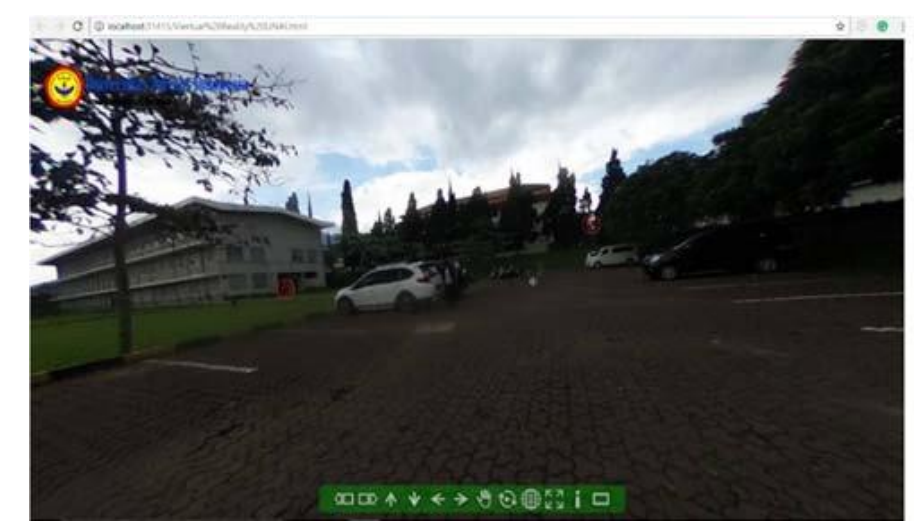

Gambar 6 Parkiran UNAI

\section{Tampilan Wifi Corner}

Tempat ini adalah salah satu layanan yang disediakan UNAI berdikusi kelompok bagi mahasiwa dan kegiatan belajar lainnya.

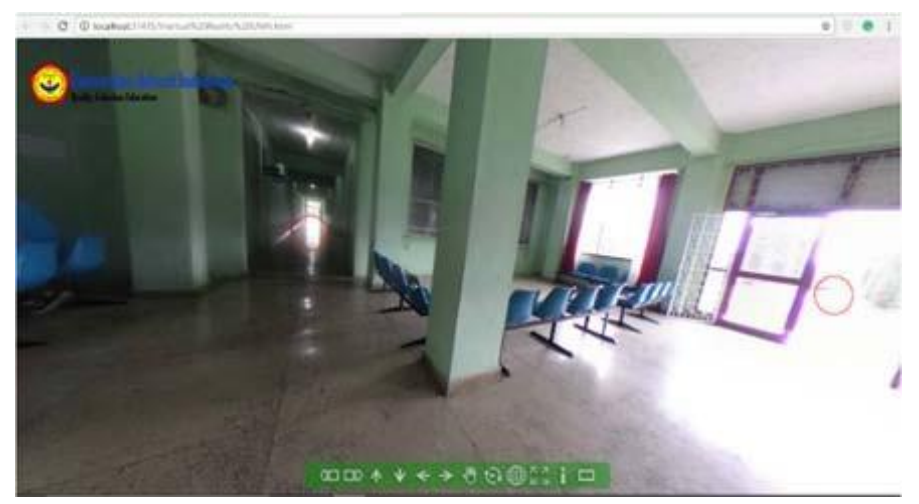

Gambar 7 Wifi Corner

\section{Kesimpulan dan Saran}

\section{Kesimpulan}

Berdasarkan hasil penelitian yang penulis lakukan dalam tugas akhir ini, maka dapat ditarik beberapa kesimpulan sebagai berikut:

1. Aplikasi Virtual Reality 360o dapat diimplementasikan kedalam website Universitas Advent Indonesia.

2. Aplikasi Virtual Reality 360 o ini menarik, interaktif dan mudah digunakan sehingga memudahkan user untuk memperoleh informasi tentang lingkungan UNAI.

\section{Saran}

Berdasarkan kesimpulan di atas, maka ada beberapa saran yang penulis berikan untuk pengembangan selanjutnya:

1. Menampilkan Informasi yang lebih lengkap lagi mengenai kampus UNAI.

2. Menggunakan kamera dengan spesifikasi yang lebih baik lagi untuk mendapatkan hasil foto panorama 3600 yang bagus dan indah.

3. Memperbaharui setiap gambar lama, jika ada yang terbaru di UNAI untuk memberikan Informasi update kepada User. 


\section{Referensi}

[1] Ahmadi dan Hermawan. 2013. E-Business \& E-Commerce. Yogyakarta: Andi.

[2] Hidayat, R., (2010), Cara Praktis Membangun Website Gratis, PT Alex Media Komputindo: Jakarta

[3] Talib, H., (2010), Panduan Praktis Menguasai Komputer, PT Alex Komputindo: Jakarta

[4] Shalahuddin, M. A., dan S., Rossa, (2010), Java di Web, Informatika: Bandung

[5] Kadir, A., (2011), Buku Pintar jQuery dan PHP, MediaKom: Yogyakarta

[6] Raghib Nuruddin. 2013. Pengertian \& Definisi Web. Tersedia: http://raghibnuruddin217.blogspot .com/. (Diakses pada tanggal 02 Februari 2017)

[7] Michael, Novak, Begus., (2014) Virtual Reality, Springer Science: New York

[8] Fuchs, Moreau, Guitton (2011), Virtual Reality, Concepts and Tecnologies, Taylor \& Francis Group: Paris

[9] Suyanto, M. 2003. Multimedia Alat Untuk meningkatkan Keunggulan Bersaing. Andi. Yogyakarta 